\title{
VIAGEM A SÃO SARUÊ: O TEMA DA TERRA EM PERSPECTIVA SEMIÓTICO-ESTILÍSTICA E DIALÓGICA
}

Morgana Ribeiro dos Santos (UERJ)

Resumo: Este artigo discute o tema da terra em que se vive ou da terra em que se gostaria de viver, elegendo-se como foco da investigação o poema de cordel "Viagem a São Saruê", de Manuel Camilo dos Santos (1978). Observa-se, com o aparato teórico da Estilística influenciada pela Semiótica e da perspectiva dialógica, como as categorias dos substantivos e adjetivos/ locuções adjetivas contribuem para a arquitetura sígnica do texto, que constrói duas linhas isotópicas opostas: a da fartura na terra imaginária São Saruê e a da escassez experimentada pela população pobre do Nordeste, prejudicada constantemente pela seca e pelas injustiças sociais. Além disso, apresentam-se outros textos da literatura canônica e cordelística, assim como do cancioneiro popular, centrados na temática do lugar em que se vive ou do lugar paradisíaco, imaginário, a fim de sugerir propostas de leitura dialógicas e enriquecer a discussão sobre a exaltação da terra.

Palavras-chave: Literatura de cordel; Viagem a São Saruê; Terra; Substantivos; Adjetivos/ locuções adjetivas; Significação.

\begin{abstract}
This article discusses the theme of the land in which one lives or of the land in which one would like to live, being chosen as the focus of the research the poem of cordel "Viagem a São Saruê", by Manuel Camilo dos Santos (1978). It is observed with the theoretical apparatus of Stylistics influenced by Semiotics and the dialogical perspective, how the categories of nouns and adjectives / adjectives phrases contribute to the signic architecture of the text, which constructs two opposing isotopic lines: that of the abundance in the imaginary earth São Saruê and the shortage experienced by the poor population of the Northeast, constantly harmed by drought and social injustices. In addition, other texts of the canonical and cordelistic literature, as well as the popular songbook, are presented, focusing on the theme of the place where one lives or of the paradisiacal and imaginary place, in order to suggest dialogical reading proposals and to enrich the discussion about the
\end{abstract}


exaltation of the earth.

Keywords: Cordel literature; Viagem a São Saruê; Earth; Nouns; Adjectives/ Adjective phrases; Meaning.

\section{APRESENTAÇÃO}

Este trabalho apresenta uma discussão que se inicia na leitura de um fragmento do cordel "Viagem a São Saruê", de Manuel Camilo dos Santos (1978), ressaltando-se o valor semiótico-estilístico dos substantivos e adjetivos/locuções adjetivas na construção de duas linhas isotópicas que orientam o sentido geral do texto em análise. A primeira enaltece a abundância da terra utópica de São Saruê, e a segunda se insinua no poema, revelando a escassez que assola as camadas mais carentes do povo brasileiro, em especial, nordestino.

A fim de enriquecer a construção dos sentidos a partir da leitura do poema "Viagem a São Saruê", aprofunda-se a reflexão sobre a temática da terra, estabelecendo diálogos com outros textos canônicos e populares que ora idealizam a terra natal ou a terra em que se vive, ora denunciam suas mazelas, sem perder, contudo, o afeto e, no caso do exilado ou do retirante, a saudade.

Além da perspectiva dialógica professada por Bakhtin (2000), a base teórica desse estudo se fundamenta em estudos estilísticos e semióticos, considerando-se textos de 
Simões (2009), Monteiro (2009), Câmara Jr. (1978), Martins (2000), Lapa (1982) e Fiorin (2008).

Cabe salientar que o presente estudo está engajado na valorização da literatura de cordel e da inventividade popular que essa manifestação registra e perpetua. Defende-se que essa poética popular deve estar inserida nas aulas de língua materna, visto que expressa o imaginário do povo em textos elaborados e com evidente riqueza sígnica.

\section{FUNDAMENTAÇÃO TEÓRICA}

A fim de sustentar a proposta de leitura do fragmento de "Viagem a São Saruê", do cordelista Manuel Camilo dos Santos (1978), e as relações dialógicas que podem ser estabelecidas com outros textos inspirados no tema da terra natal ou terra em que se vive, consideram-se, inicialmente, os estudos de Simões (2009). A autora desenvolve suas pesquisas em Semiótica com base nos trabalhos de Peirce, que, segundo ela, "não se ocupou do signo verbal, senão da construção de uma teoria universal que abrigasse signos de qualquer natureza" (p.63). Na perspectiva de Simões (2009), o signo é dinâmico, ou seja, é um "objeto que se movimenta em meio aos movimentos sociais e que se cria e recria cotidianamente" (p.21). 
O signo pode se caracterizar como símbolo - natureza convencional -, índice - representando determinado objeto com base na contiguidade - ou ícone - funcionando a partir da similaridade. Simões (2009) aponta a manifestação da iconicidade na seleção, organização e emprego dos recursos linguísticos. Segundo a autora,

É observável: a seleção vocabular como representativa de usos e costumes diversos; a colocação dos termos nos enunciados como imagem das opções de enfoque ou das posições discursivas; a eleição do gênero e do tipo textual como indicador da relevância dos itens temáticos e lexicais contemplados no texto etc. Também o projeto de texto, sua arquitetura visual ou sonora, é material icônico a ser observado. (p.78)

Simões argumenta que "a iconicidade será tão mais eficiente (no que concerne à representação de seu objeto) quanto mais adequada for a seleção de itens léxicos (palavras ou expressões) por parte do enunciador" (2009, p.84). Nessa perspectiva, entende-se a importância do léxico para a representação do mundo por meio da linguagem.

A autora ressalta a importância da iconicidade isotópica para a construção do sentido. Isotopia, segundo a semioticista, é a "propriedade de um enunciado ser substituído por equivalente no plano do conteúdo, embora sejam diferentes 
no plano da expressão. Dessa forma tem-se a isotopia numa tomada sinonímica" (2009, p.88). Simões defende, todavia, que essa noção seja ampliada, afirmando que "é possível (...) defini-la como a possibilidade de um recorte temático" (2009, p.89).

Simões destaca que os recortes temáticos ou isotópicos são estabelecidos pelo emprego do léxico. Nas palavras da pesquisadora, "a garantia dos recortes isotópicos propostos para esse ou aquele texto se assenta exatamente na possibilidade de identificação de itens léxicos (palavras ou expressões) que constituam campos lexicais ou campos semânticos" (2009, p.89). Como exemplo, a autora cita as isotopias da traição e do ciúme que conduzem o romance Dom Casmurro, de Machado de Assis.

Simões salienta a seleção e a aplicação elaborada dos elementos linguísticos como procedimentos desencadeadores de efeitos especiais de sentido. Segundo a estudiosa,

Não é novidade que os signos verbais sejam regulados por uma gramática. No entanto, o arranjo destes na produção dos enunciados muitas vezes transcende as normas gramaticais estabelecidas e gera novas possibilidades estruturais sem que com isso a gramática seja aviltada. Cumpre lembrar que as normas existem 
para regular um padrão de produção ao alcance da média de utentes. No entanto, há fórmulas não-previstas, às vezes surpreendentes, que enriquecem a expressão e amplificam o potencial semiótico do texto: ora pela escolha do item sígnico mais apropriado ora pelo arranjo mais estratégico dos signos. (SIMÕES, 2009, p.93-94)

Nessa perspectiva, as observações da semioticista, que também produziu trabalhos orientados pela Estilística, apresentam uma interseção com a ciência que se ocupa do estilo ou "a expressão dos fatos da sensibilidade pela linguagem e a ação dos fatos de linguagem sobre a sensibilidade", conforme estabelecido por Charles Bally (Apud MONTEIRO, 2009, p.39).

Segundo Câmara Jr. (1978), “a estilística vem complementar a gramática" (p.14), investigando os desvios do sistema linguístico, que inscrevem no discurso uma personalidade ou estilo. O estudioso explica que o sistema linguístico proporciona certo grau de liberdade ao falante, o que dá margem à atividade criadora. Em outras palavras, "a liberdade que a língua faculta num ou noutro ponto permitenos ser originais continuando, pelo menos, inteligíveis; e essa oportunidade o nosso espírito logo aproveita para o fim das suas exigências expressivas" (p.16). 
Câmara Jr. afirma que um dos propósitos da Estilística é a "depreensão desse mecanismo de motivações que a linguagem expressiva estabelece, entre o significante e o significado" (1978, p.19). Ou seja, a Estilística, até certo ponto, questiona ou relativiza a arbitrariedade do signo linguístico, postulada por Saussure: "a carga expressiva, estendendo-se a todos os elementos linguísticos, forceja por anular o princípio da arbitrariedade, sob cuja égide eles se constituíram" (1978, p.18).

O estilo, segundo o autor, não se limita ao plano individual. Reconhecido o valor social da linguagem, Câmara Jr. amplia a noção de estilo para o plano coletivo: "o estilo individual se esbate, assim, no estilo de uma época, de uma classe, de uma cidade, de um país. E é desta sorte que se pode falar até no estilo de uma língua, como pôs em evidência Bally para o francês em cotejo com o alemão" (1978, p.16).

Nas palavras do estudioso:

Visando à pesquisa da personalidade linguística, podemos fazer a estilística de um sujeito falante especialmente dotado, e, no âmbito literário, concentrarmo-nos num poeta ou num pensador de nota. Dada, por outro lado, a circunstância de que o estilo tende a ser um denominador comum de um grupo humano coeso, podemos no mesmo sentido tratar de uma época, ou de uma escola literária, 
ou de uma classe social, ou investigar uma gíria, quer entendida como calão de malfeitores, onde se exteriorizam recalques e impulsos afetivos, quer ainda, lato-sensu, como um estilo popular coletivo. (CAMARA JR., 1978, p.23)

Martins (2000), tratando da estilística da palavra, afirma que os substantivos e adjetivos/locuções adjetivas classes de que se ocupa o presente trabalho - se incluem na categoria das palavras lexicais, "também chamadas lexicográficas, nocionais, reais, plenas" (p.77). A autora explica que essas palavras, "mesmo isoladas, fora da frase, despertam em nossa mente uma representação, seja de seres, seja de ações, seja de qualidades de seres ou modos de ações" (p.77). Segundo Martins, as palavras lexicais "têm significação extralinguística ou externa, visto que remetem a algo que está fora da língua e que faz parte do mundo físico, psíquico ou social" (p.77).

Lapa, a respeito do valor estilístico do substantivo, observa que "pouco difere do adjetivo, são dois aspectos duma mesma realidade linguística" (1982, p.92). Segundo o autor, "a própria origem do nome tem mais de adjetivo do que de substantivo" (1982, p.92), já que "ao princípio, todos os seres foram designados por uma qualidade fundamental que os caracterizava" (1982, p.92). O estudioso ressalta a 
importância do adjetivo na arte de escrever, pois a aplicação precisa dessa categoria de palavras a fim de contribui para "dar cor a tudo, às coisas e aos pensamentos" (1982, p.99).

A fim de subsidiar a leitura dialógica do fragmento do cordel "Viagem a São Saruê" em cotejo com outros textos da poesia canônica e cordelística e letras de música do cancioneiro popular, consideram-se os estudos de Bakhtin (2000). Sobre a relação dialógica entre os enunciados, o autor explica que o discurso sempre recebe uma atitude do ouvinte como resposta.

De fato, o ouvinte que recebe e compreende a significação (linguística) de um discurso adota simultaneamente, para com este discurso, uma atitude responsiva ativa: ele concorda ou discorda (total ou parcialmente), completa, adapta, apronta-se para executar, etc., e esta atitude do ouvinte está em colaboração constante durante todo o processo de audição e de compreensão desde o início do discurso, às vezes já nas primeiras palavras emitidas pelo locutor. (p. 290)

Nessa perspectiva, a "atitude responsiva ativa" transforma o ouvinte em produtor de discurso. Nas palavras do estudioso: "toda compreensão é prenhe de resposta e, de uma forma ou de outra, forçosamente a produz: o ouvinte torna-se o locutor" (p.290). 
Segundo a orientação bakhtiniana, a interação humana ocorre em uma cadeia complexa de enunciados que são produzidos a partir de outros, em um processo contínuo.

O próprio locutor como tal é, em certo grau, um respondente, pois não é o primeiro locutor, que rompe pela primeira vez o eterno silêncio de um mundo mudo, e pressupõe não só a existência do sistema da língua que utiliza, mas também a existência dos enunciados anteriores - emanantes dele mesmo ou do outro - aos quais seu próprio enunciado está vinculado por algum tipo de relação (fundamentase neles, polemiza com eles), pura e simplesmente ele já os supõe conhecidos do ouvinte. Cada enunciado é um elo da cadeia muito complexa de outros enunciados. (BAKHTIN, 2000, p.291)

Bakhtin (2000) esclarece que os enunciados carregam reminiscências de outros com os quais dialogam. Nas palavras do autor, "o enunciado está repleto dos ecos e lembranças de outros enunciados, aos quais está vinculado no interior de uma esfera comum da comunicação verbal” (p.316). O estudioso afirma ainda que o enunciado é uma "resposta a enunciados anteriores", pois "refuta-os, confirma-os, completa-os, baseia-se neles, supõe-nos conhecidos e, de um modo ou de outro, conta com eles" (p.316).

Em estudo sobre o pensamento de Bakhtin, Fiorin 
(2008) distingue enunciado e texto. O enunciado, segundo o pesquisador, é "um todo de sentido, marcado pelo acabamento, dado pela possibilidade de admitir uma réplica" (p.52), corresponde a "uma posição assumida por um enunciador" (p.52). Fiorin afirma que "o texto é a manifestação do enunciado, é uma realidade imediata, dotada da materialidade, que advém do fato de ser um conjunto de signos" (p.52). Nessa perspectiva, "há relações dialógicas entre enunciados e entre textos" (p.52). As relações dialógicas materializadas em textos são chamadas, segundo o estudioso, intertextualidade.

Na próxima seção, será apresentada uma análise concentrada nos efeitos de sentido decorrentes dos substantivos e adjetivos/locuções adjetivas empregados no poema de cordel "Viagem a São Saruê", de Manuel Camilo dos Santos (1978). Além disso, investiga-se o diálogo desse texto com outros que se inspiram no tema da terra natal ou terra em que se vive, a fim de subsidiar o trabalho docente no ensino de leitura nas aulas de Língua Portuguesa.

\section{ANÁLISE DO CORPUS}

Nesta proposta de leitura, aborda-se o tema da terra, elemento importantíssimo na literatura de cordel, devido às suas raízes rurais. O lugar em que se vive ou o lugar em que 
se deseja viver sempre inspira os poetas, sejam populares ou da literatura considerada canônica.

A discussão será iniciada a partir da leitura do poema "Viagem a São Saruê" (Apud SILVA, 2008, p.311), do cordelista Manuel Camilo dos Santos (1978), que nasceu em 1905, em Guarabira, Paraíba, e faleceu em 1987. O poema, rico em lirismo e utopia, narra uma viagem imaginária à terra encantada de São Saruê, uma espécie de paraíso onde os habitantes desfrutam de saúde, riqueza e felicidade.

Doutor mestre pensamento me disse um dia: - Você

Camilo vá visitar o país de São Saruê pois é o lugar melhor que neste mundo se vê.

Eu que desde pequenino sempre ouvia falar nesse tal São Saruê destinei-me a viajar com ordem do pensamento fui conhecer o lugar.

Iniciei a viagem as quatro da madrugada tomei o carro da brisa passei pela alvorada junto do quebrar da barra e vi a aurora abismada.

Pela aragem matutina eu avistei bem defronte 
o irmão da linda aurora que se banhava na fonte já o sol vinha espargindo no além do horizonte.

Surgiu o dia risonho na primavera imponente as horas passaram lentas o espaço incandescente transformava a brisa mansa em um mormaço dolente.

Passei do carro na brisa para o carro do mormaço o qual veloz penetrou no além do grande espaço nos confins do horizonte senti do dia o cansaço.

Enquanto a tarde caía entre mistérios e segredos a viração docilmente afagava os arvoredos os últimos raios de sol bordavam os altos penedos.

Morreu a tarde e a noite assumiu sua chefia deixei o mormaço e passei pro carro da neve fria vi os mistérios da noite esperando pelo dia.

Ao surgir da nova aurora senti o carro pairar olhei e vi uma praia sublime de encantar 
o mar revolto banhando as dumas da beira mar.

Avistei uma cidade como nunca vi igual toda coberta de ouro e forrada de cristal ali não existe pobre é tudo rico em geral.

Uma barra de ouro puro servindo de placa eu vi com as letras de brilhante chegando mais perto eu li dizia: - São Saruê é este lugar aqui.

Quando avistei o povo fiquei de tudo abismado uma gente alegre e forte um povo civilizado bom, tratável e benfazejo por todos fui abraçado.

O povo em São Saruê tudo tem felicidade passa bem anda decente não há contrariedade não precisa trabalhar e tem dinheiro à vontade.

Lá os tijolos das casas são de cristal e marfim as portas barras de prata fechaduras de "rubim" as telhas folhas de ouro e o piso de cetim. 
Lá eu vi rios de leite barreiras de carne assada lagoas de mel de abelha atoleiros de coalhada açudes de vinho do porto montes de carne guisada.

As pedras em São Saruê são de queijo e rapadura as cacimbas são café já coado e com quentura de tudo assim por diante existe grande fartura.

Feijão lá nasce no mato maduro e já cozinhado o arroz nasce nas várzeas já prontinho e despolpado peru nasce de escova sem comer vive cevado.

Galinha põe ovo todo dia invés de ovos é capão o trigo invés de sementes bota cachadas de pão manteiga lá cai das nuvens fazendo ruma no chão.

Os peixes lá são tão mansos com o povo acostumados saem do mar vem pras casas são grandes, gordos, cevados é só pegar e comer pois todos vivem guisados.

Tudo lá é bom e fácil não precisa se comprar 
não há fome nem doença o povo vive a gozar tem tudo e não falta nada sem precisar trabalhar.

Maniva lá não se planta nasce e ao invés de mandioca bota cachos de beiju e palmas de tapioca milho a espiga é pamonha e o pendão é pipoca.

As canas em São Saruê não tem bagaço (é gozado) umas são canos de mel outras açúcar refinado as folhas são cinturão de pelica e bem cromado.

Lá os pés de casimira brim, borracha e tropical denaycron, belga e linho e o famoso diagonal já bota roupas prontas próprias para o pessoal.

Os pés de chapéu de massa são tão carregados os de sapatos da moda têm cachos "aloprados" os pés de meias de seda chega vive "escangalhados".

Sítios de pés de dinheiro que faz chamar a atenção os cachos de notas grandes chega arrastam pelo chão 
as moitas de prata e ouro são mesmo que algodão.

Os pés de notas de mil carrega chega encapota pode tirar-se à vontade quanto mais tira mais bota além dos cachos que tem casca e folhas tudo é nota.

Lá quando nasce um menino não dá trabalho criar já é falando e já sabe ler, escrever e contar salta, corre, anda e faz tudo quanto se mandar.

Lá não se vê mulher feia e toda moça é formosa bem educada e decente bem trajada e amistosa é qual um jardim de fadas repleto de cravo e rosa.

Lá tem um rio chamado o banho da mocidade onde um velho de cem anos tomando banho à vontade quando sai fora parece Ter vinte anos de idade.

É um lugar magnífico onde eu passei muitos dias bem satisfeito e gozando prazer, saúde, alegrias todo esse tempo ocupei-me em recitar poesias. 
Lá existe tudo quanto é beleza tudo quanto é bom, belo e bonito, parece um lugar santo e bendito ou um jardim da divina Natureza: imita muito bem pela grandeza a terra da antiga promissão para onde Moisés e Aarão conduziram o povo de Israel, onde dizem que corria leite e mel e caía manjar do céu no chão.

Tudo lá é festa e harmonia amor, paz, benquerer, felicidade descanso, sossego e amizade prazer, tranquilidade e alegria; na véspera de eu sair naquele dia um discurso poético, lá, eu fiz, me deram a mandado de um juiz um anel de brilhante e de "rubim" no qual um letreiro dizia assim: - é feliz quem visita este país.

Vou terminar avisando a qualquer amiguinho que quiser ir para lá posso ensinar o caminho porém só ensino a quem me comprar um folhetinho.

O poema de Manuel Camilo dos Santos apresenta trinta e três estrofes, trinta e uma sextilhas em redondilha maior, nas quais rimam o segundo, o quarto e o sexto versos, e duas décimas de versos decassílabos, em que o primeiro verso rima com o quarto e o quinto, o segundo verso rima 
com o terceiro, o sexto verso rima com o sétimo e o décimo, o oitavo rima com o nono. A sextilha, modelo de estrofe predominante no poema, segundo Viana (2010), é a principal modalidade de estrofe do cordel (p.35).

Nos versos de Manuel Camilo dos Santos, descrevese uma terra idealizada e incomum, ou seja, estranha à realidade conhecida. A terra de São Saruê se assemelha à Canaã bíblica, citada na trigésima primeira estrofe, terra prometida por Deus ao povo hebreu: "uma terra boa e larga, [...] que mana leite e mel" (Êxodo, 3.8). A terra de São Saruê é rica, revestida com os materiais mais preciosos: ouro, cristal, brilhante, marfim, prata, rubim (rubi), cetim, sua natureza é farta, os alimentos são abundantes, há disponibilidade de bens materiais, como vestimentas, e imateriais, como inteligência, beleza, poesia, e seus habitantes vivem em situação de igualdade.

Em virtude da extensão do poema, destacamos para uma análise mais cuidadosa treze estrofes do texto, da décima até a vigésima segunda, nas quais descreve-se o país de São Saruê e enfatiza-se a abundância de alimentos.

Percebe-se no fragmento em análise duas linhas isotópicas, a da riqueza de São Saruê e a da escassez que maltrata o nordestino. A linha isotópica da abundância é 
explícita, enquanto a da pobreza se insinua. Todavia, esta última é a que sustenta a oposta, relativa ao delírio da terra de São Saruê. A compreensão da pobreza experimentada pela maioria da população nordestina depende, na leitura desse texto, da atenção à linha isotópica implícita.

A fartura de São Saruê e a qualidade de vida de seus habitantes são construídas, no poema, sobretudo, pelo emprego de substantivos, adjetivos e locuções adjetivas. Na tabela abaixo, apresentam-se essas classes de palavras, que descrevem a terra paradisíaca e deixam escapar pistas da realidade conhecida pelo poeta e seus conterrâneos.

\begin{tabular}{|l|l|l|}
\hline $\begin{array}{l}\text { Substantivos } \\
\text { eadjetivos/ } \\
\text { locuções adjetivas }\end{array}$ & São Saruê & Realidade \\
\hline Estrofe 10 & $\begin{array}{l}\text { Cidade (como nunca vi) igual, coberta } \\
\text { de ouro, forrada de cristal, rico }\end{array}$ & Pobre \\
\hline Estrofe 11 & $\begin{array}{l}\text { Barra de ouro puro, placa, letras de } \\
\text { brilhante, São Saruê, lugar }\end{array}$ & \\
\hline Estrofe 12 & $\begin{array}{l}\text { Povo, gente alegre e forte, (povo) } \\
\text { civilizado, bom, tratável, benfazejo }\end{array}$ & Abismado \\
\hline Estrofe 13 & $\begin{array}{l}\text { Povo, São Saruê, felicidade, decente, } \\
\text { dinheiro }\end{array}$ & Contrariedade \\
\hline Estrofe 14 & $\begin{array}{l}\text { Tijolos das casas, de cristal e marfim, } \\
\text { portas, barras de prata, fechaduras de } \\
\text { "rubim", telhas, folhas de ouro, piso de } \\
\text { cetim } 15\end{array}$ & $\begin{array}{l}\text { Rios de leite, barreiras de carne assada, } \\
\text { lagoas de mel de abelha, atoleiros de } \\
\text { coalhada, açudes de vinho do porto, } \\
\text { montes de carne guisada }\end{array}$ \\
\hline Estrofe 16 & $\begin{array}{l}\text { Pedras, São Saruê, (pedras) de queijo e } \\
\text { rapadura, cacimbas, café coado e com } \\
\text { quentura, grande fartura }\end{array}$ & \\
\hline
\end{tabular}




\begin{tabular}{|l|l|l|}
\hline Estrofe 17 & $\begin{array}{l}\text { Feijão maduro, cozinhado, mato, arroz } \\
\text { prontinho e despolpado, várzeas, peru } \\
\text { cevado }\end{array}$ & \\
\hline Estrofe 18 & $\begin{array}{l}\text { Galinha, ovos, capão, trigo, sementes, } \\
\text { cachadas de pão, manteiga, nuvens, } \\
\text { ruma, chão. }\end{array}$ & \\
\hline Estrofe 19 & $\begin{array}{l}\text { Peixes mansos, povo, (peixes) } \\
\text { acostumados, mar, casas, (peixes) } \\
\text { grandes, gordos, cevados, guisados }\end{array}$ & \\
\hline Estrofe 20 21 & $\begin{array}{l}\text { Bam, fácil, povo } \\
\text { palmas de tapioca, milho, espiga, } \\
\text { pamonha, pendão, pipoca }\end{array}$ & \\
\hline Estrofe 22 & $\begin{array}{l}\text { Canas, São Saruê, bagaço, canos de } \\
\text { mel, açúcar refinado, folhas, cinturão } \\
\text { de pelica, cromado }\end{array}$ & Gozado \\
\hline
\end{tabular}

Tabela 1 - Recortes isotópicos em "Viagem a São Saruê", de Manuel Camilo dos Santos (1978)

Diante da notável quantidade de substantivos e adjetivos/ locuções adjetivas que assinalam a riqueza e a fartura de alimentos de São Saruê, que nascem sem a necessidade do árduo trabalho do agricultor, o foco será colocado nas palavras que estabelecem a oposição entre realidade e sonho. Na décima estrofe, o adjetivo "pobre", substantivado, em relação ao antônimo "rico", que caracteriza o povo de São Saruê, revela a realidade vivenciada pelo sujeito poético: a da escassez.

Na décima segunda estrofe, o adjetivo "abismado" expressa a admiração do eu lírico ao vislumbrar São Saruê. Na mesma perspectiva, na vigésima segunda estrofe, o adjetivo "gozado", referente ao que se observa na terra maravilhosa, denota a surpresa de quem não está acostumado com a 
abundância ali encontrada. Na décima terceira estrofe, afirma-se que a "contrariedade" não existe em São Saruê, em contraste, o que existe é a "felicidade". Os substantivos "fome" e "doença", na vigésima estrofe, estabelecem oposição a tudo o que há no país encantado, revelando o que se experimenta fora dos limites da utopia.

Um diálogo muito proveitoso com o poema de Manuel Camilo dos Santos pode se desenvolver a partir do cotejo com outros textos que exaltam uma terra imaginária ou idealizam a terra natal, como o poema "Vou-me embora pra Pasárgada", de Manuel Bandeira (1993, p.143):

Vou-me embora pra Pasárgada

Lá sou amigo do rei

Lá tenho a mulher que eu quero

Na cama que escolherei

Vou-me embora pra Pasárgada

Vou-me embora pra Pasárgada

Aqui eu não sou feliz

Lá a existência é uma aventura

De tal modo inconsequente

Que Joana a Louca da Espanha

Rainha e falsa demente

Vem a ser contraparente

Da nora que nunca tive

E como farei ginástica

Andarei de bicicleta

Montarei em burro brabo

Subirei no pau-de-sebo 
Tomarei banhos de mar!

E quando estiver cansado Deito na beira do rio

Mando chamar a mãe-d'água

Pra me contar as histórias

Que no tempo de eu menino

Rosa vinha me contar

Vou-me embora pra Pasárgada

Em Pasárgada tem tudo

É outra civilização

Tem um processo seguro

De impedir a concepção

Tem telefone automático

Tem alcalóide à vontade

Tem prostitutas bonitas

Para a gente namorar

E quando eu estiver mais triste

Mas triste de não ter jeito

Quando de noite me der

Vontade de me matar

- Lá sou amigo do rei -

Terei a mulher que eu quero

$\mathrm{Na}$ cama que escolherei

Vou-me embora pra Pasárgada.

Outros diálogos pertinentes podem ser estabelecidos com poemas que exaltam e idealizam a terra natal, temática comum tanto na literatura canônica quanto na popular. $\mathrm{O}$ clássico "Canção do Exílio", de Gonçalves Dias (1846), e o cordel "Parque Pedra da Boca", de Gil Ribeiro (2007), são bons exemplos. 
O tema do lugar em que se vive é tão importante que foi eleito, desde 2008, como matéria das Olimpíadas de Língua Portuguesa, concurso nacional de redação para alunos das escolas públicas, do sexto ano do Ensino Fundamental ao terceiro ano do Ensino Médio. Segundo o portal eletrônico do MEC, o tema "O Lugar Onde Vivo" desse concurso é "destinado a valorizar a interação das crianças e jovens com o meio em que crescem. Ao desenvolver os textos, o aluno resgata histórias, aprofunda o conhecimento sobre a realidade e estreita vínculos com a comunidade" (http:// portal.mec.gov.br/component/tags/tag/34492. Acesso em 01 nov. 2016.).

Os versos de Gonçalves Dias, compostos em Portugal, revelam saudades da terra natal e exaltam os encantos das terras brasileiras:

Minha terra tem palmeiras, Onde canta o Sabiá;

As aves, que aqui gorjeiam, Não gorjeiam como lá.

Nosso céu tem mais estrelas, Nossas várzeas têm mais flores, Nossos bosques têm mais vida, Nossa vida mais amores.

Em cismar, sozinho, à noite, Mais prazer encontro eu lá; Minha terra tem palmeiras, Onde canta o Sabiá. 
Minha terra tem primores, Que tais não encontro eu cá; Em cismar - sozinho, à noite Mais prazer encontro eu lá; Minha terra tem palmeiras, Onde canta o Sabiá.

Não permita Deus que eu morra, Sem que volte para lá;

Sem que desfrute os primores

Que não encontro por cá;

Sem qu'inda aviste as palmeiras, Onde canta o Sabiá.

(O Estado de São Paulo. Clássicos da Poesia Brasileira: Antologia da Poesia Brasileira Anterior ao Modernismo. (1997. p.66-67)

Em cotejo com os poemas de elogio a terras imaginárias, o poema de Gonçalves Dias guarda semelhanças e diferenças. O poema descreve a natureza exuberante do Brasil, que é real, todavia, o sentimento nacionalista inebria os versos de Gonçalves Dias, culminando na idealização romântica da terra natal. Vale ressaltar que esse poema inspirou a composição do Hino Nacional Brasileiro, com letra de Joaquim Osório Duque Estrada e música de Francisco Manuel da Silva, como pode ser observado na segunda estrofe da Parte II do hino:

Do que a terra, mais garrida, Teus risonhos, lindos campos têm mais flores;

"Nossos bosques têm mais vida", "Nossa vida" no teu seio "mais amores". (http://www.planalto.gov.br/ccivil_03/ 
Constituicao/hino.htm Acesso em 01Nov.2016)

Apresentam-se abaixo sete estrofes do cordel "Parque Pedra da Boca", de Gil Ribeiro (2007). O cordel de Ribeiro - poeta nascido em 1967, em Serra de São Bento (RN), na fronteira com a Paraíba - se ocupa de descrever e exaltar o Parque Estadual da Pedra da Boca, localizado no município de Araruna, Paraíba, no limite com o Rio Grande do Norte.

Nesse local se avista Nosso parque por inteiro, As terras do calabouço Com o Sítio de Coqueiros Até cidades vizinhas Avista-se nesta linha Sem gastar nenhum dinheiro.

Também quero abordar Sobre a Pedra do Carneiro É na chegada do Parque Bem antes da do Letreiro, Ela é média e redondada Fica na beira da estrada Próximo duns pés de coqueiros.

Além dessas duas pedras É bom visitar também Outras raras maravilhas Que o nosso parque tem Como a Pedra da Caveira Que está na cordilheira Sem nunca assustar ninguém.

Sem dúvida a mais renomada 
É a Pedra do Letreiro,

Sua pintura rupestre

É fonte pra o brasileiro

Estudar nosso passado

Vem gente de todo lado

Até mesmo do estrangeiro.

Ali sempre é visitado

Por matuto e doutor

Vem gente das faculdades

Estudante e professor

Estudar nossa pintura

Porém, aquela leitura

É vista com muito amor.

Acredita-se que o homem

Quando morava em caverna

Registrara sua marca

Símbolo da cultura eterna

Por isso nosso letreiro

É visto no mundo inteiro

Orgulhando nossa terra.

Porém com esse letreiro

O nosso turismo avança

Além disso é privilégio

A imagem duma santa

Que há muito tempo está

Naquele lindo lugar

Relembro desde criança

O poema de Gil Ribeiro se organiza em setilhas ou sétimas, com versos de sete sílabas poéticas ou redondilha maior. 0 poeta rima o segundo verso com o quarto e o sétimo, e o quinto verso com o sexto. Vale salientar que a redondilha 
maior, observada tanto no poema de Gonçalves Dias quanto no de Gil Ribeiro, constitui a métrica favorita dos cordelistas.

Os versos de Ribeiro exaltam as riquezas naturais e arqueológicas do parque, seu potencial turístico e destacam, sobretudo, na antítese "matuto"/ "doutor", registrada na quinta estrofe do fragmento, o parque como um tesouro que serve como elo entre os homens de diferentes condições, procedências e níveis de escolaridade, ou seja, o parque une os homens com o encantamento decorrente de sua beleza e história.

Entretanto, não só a poesia apresenta variedade de textos que louvam a terra natal ou a terra em que se vive. Textos de variados gêneros e tradições se ocupam desse relevante tema, por exemplo, letras de música.

O samba "Meu lugar", de Arlindo Cruz e Mauro Diniz, gravado no álbum Sambista Perfeito (http://arlindocruz.com. br/2007-sambista-perfeito/ Acesso em 12 nov. 2016), em 2007, enaltece o bairro carioca de Madureira, destacando a religiosidade, as crenças, a cultura, o modo de viver e as raízes afrodescendentes da população local.

O meu lugar

É caminho de Ogum e lansã

Lá tem samba até de manhã

Uma ginga em cada andar 
O meu lugar

É cercado de luta e suor

Esperança num mundo melhor

E cerveja pra comemorar

O meu lugar

Tem seus mitos e seres de luz

É bem perto de Osvaldo Cruz,

Cascadura, Vaz Lobo e Irajá

O meu lugar

É sorriso, é paz e prazer

O seu nome é doce dizer

Madureira, lá laiá, Madureira, lá laiá

Ahh que lugar

A saudade me faz relembrar

Os amores que eu tive por lá

É difícil esquecer

Doce lugar

Que é eterno no meu coração

E aos poetas traz inspiração

Pra cantar e escrever

Ai meu lugar

Quem não viu Tia Eulália dançar

Vó Maria o terreiro benzer

E ainda tem jongo à luz do luar

Ai que lugar

Tem mil coisas pra gente dizer

$O$ difícil é saber terminar

Madureira, lá laiá, Madureira, lá laiá,

Madureira 
Em cada esquina um pagode num bar Em Madureira Império e Portela também são de lá Em Madureira E no Mercadão você pode comprar Por uma pechincha você vai levar Um dengo, um sonho pra quem quer sonhar

Em Madureira

E quem se habilita até pode chegar Tem jogo de lona, caipira e bilhar Buraco, sueca pro tempo passar Em Madureira

E uma fezinha até posso fazer No grupo dezena, centena e milhar Pelos sete lados eu vou te cercar Em Madureira E lalalaiala laia la la ia Em Madureira

A canção de Arlindo Cruz e Mauro Diniz é tão representativa de Madureira e da cultura suburbana, que inspirou o livro de crônicas $O$ meu lugar, organizado por Luiz Antônio Simas e Marcelo Moutinho, sobre bairros do Rio de Janeiro e arredores, lançado em 2015 (http://odia.ig.com.br/noticia/ rio-de-janeiro/2015-10-14/o-meu-lugar-de-arlindo-cruz-emauro-diniz-inspira-livro-de-cronicas-do-rio.html Acesso em 12.Nov.2016).

Além do diálogo com textos que enaltecem a terra real ou utópica, discussões proveitosas podem ocorrer nas aulas de língua materna ao debater-se o poema "Viagem a São Saruê" 
em cotejo com textos que denunciam os problemas do lugar em que se vive ou do lugar em que se gostaria de viver. São comuns nas produções textuais nordestinas as queixas contra a seca, a fome, as desigualdades sociais, as condições de vida adversas enfrentadas pelos nordestinos pobres. Como contraponto à descrição idealizada da terra abundante de São Saruê, "Asa Branca", um clássico do cancioneiro nordestino, composto por Luiz Gonzaga e Humberto Teixeira, em 1947, sem deixar de lado o amor pela terra natal e a dor da saudade, lamenta a escassez de recursos em decorrência da seca.

Quando oiei a terra ardendo

Qual fogueira de São João

Eu preguntei

A Deus do céu, ai

Pru que tamanha judiação

Qui braseiro, qui fornaia

Nem um pé de prantação

Pru farta d'água

Perdi meu gado

Morreu de sede meu alazão

Inté mesmo a asa branca

Bateu asas do sertão

Entonce eu disse

Adeus Rosinha

Guarda contigo meu coração

Hoje longe muitas léguas

Numa triste solidão 
Espero a chuva

Cair de novo

Pra mim vortá pro meu sertão

Quando o verde dos teus óio

Se espaiá na prantação

Eu te asseguro

Num chore não, viu?

Qui eu vortarei, viu, meu coração

(GONZAGA, Luiz. Asa Branca. In: $O$

melhor de Luiz Gonzaga. Rio de Janeiro:

Sony Music, 1989. Faixa n. 1)

Sabe-se que os enunciados são prenhes de resposta.

Os enunciados que expressam denúncia ou queixas exemplificam isso com muita evidência. A canção de Luiz Gonzaga e Humberto Teixeira roga, tentando alcançar, pela beleza de sua lamentação, tanto os homens quanto o próprio Deus, a fim de obter a graça de viver em sua terra natal com dignidade.

Elegendo-se como ponto de partida desta seção o cordel "Viagem a São Saruê", de Manuel Camilo dos Santos, verificou-se a importância da terra em que se vive ou da terra em que se gostaria de viver como tema de produções textuais. O estudo dos substantivos e adjetivos/locuções adjetivas no texto de Manuel Camilo revela a utopia de viver em uma terra abundante, rica e igualitária, que se opõe à realidade experimentada, especialmente, pela população carente do Nordeste. 


\section{CONSIDERAÇÕES FINAIS}

A partir da leitura do poema de cordel "Viagem a São Saruê", de Manuel Camilo dos Santos (1978), observou-se o valor semiótico-estilístico dos substantivos e adjetivos/ locuções adjetivas na arquitetura sígnica do texto em foco. Identificaram-se duas linhas isotópicas no poema de Manuel Camilo: uma que exalta a riqueza da terra imaginária de São Saruê, e outra que se insinua, revelando as dificuldades enfrentadas pela população mais carente do Nordeste, representada pelo poeta cordelista.

A fim de ampliar a proposta de leitura do cordel "Viagem a São Saruê", apresentaram-se outros textos da poesia cordelística e canônica, assim como letras de música do cancioneiro popular, que atestam a possibilidade de leituras dialógicas entre o cordel de Manuel Camilo dos Santos e os demais textos apresentados. Seja construindo um paraíso imaginário, valorizando as características da terra natal ou da terra em que se vive, ou denunciando suas mazelas, a Língua Portuguesa é plena de belíssimos textos cuja elaboração permite significar a esperança de viver feliz e dignamente.

A literatura de cordel, ao lado da literatura canônica e de outras manifestações da cultura popular, pode contribuir para o ensino da leitura e para ricas discussões sobre a Língua 
Portuguesa e suas possibilidades. O poema de cordel "Viagem a São Saruê" expressa a dura realidade experimentada pelos nordestinos prejudicados pela pobreza e a utopia de viver em abundância, por meio da seleção e aplicação elaborada dos recursos disponíveis no sistema da língua materna.

\section{REFERÊNCIAS}

BAKHTIN, Mikhail (2000). Estética da Criação Verbal. São Paulo: Martins Fontes.

BANDEIRA, Manuel (1993). Estrela da Vida Inteira. 21.ed. Rio de Janeiro: Nova Fronteira.

BíBLIA. (1995). Bíblia de Estudo Pentecostal. João Ferreira de Almeida (Trad.). CPAD.

CÂMARA Jr. Joaquim Mattoso (1978). Contribuição à Estilística Portuguesa. Rio de Janeiro: Ao Livro Técnico.

FIORIN, José Luiz (2008). Introdução ao pensamento de Bakhtin. São Paulo: Ática.

GONZAGA, Luiz (1989). Asa Branca. In: O melhor de Luiz Gonzaga. Faixa n.1. Rio de Janeiro: Sony Music.

LAPA, Manuel Rodrigues (1982). Estilística da língua portuguesa. 11.ed. São Paulo: Martins Fontes.

MARTINS, Nilce Sant'Anna (2000). Introdução à Estilística. 3.ed. São Paulo: T. A. Queiroz.

MONTEIRO, José Lemos (2009). A Estilística: Manual de análise e criação do estilo literário. 2.ed. Petrópolis: Vozes.

O ESTADO DE SÃO PAULO (1997). Clássicos da Poesia Brasileira: Antologia da Poesia Brasileira Anterior ao Modernismo.

RIBEIRO, Gil (2007). Parque Pedra da Boca. Folheto.

SANTOS, Manuel Camilo dos. Viagem a São Saruê (1978). Apud SILVA, 
Gonçalo Ferreira da. Cem cordéis históricos segundo a Academia Brasileira de Literatura de Cordel. Mossoró: Queima-Bucha.

SIMÕES, Darcilia (2009). Iconicidade Verbal: Teoria e Prática. Rio de Janeiro: Dialogarts.

VIANA, Arievaldo Lima (Orgs.) (2010). Acorda cordel na sala de aula: A Literatura Popular como ferramenta auxiliar na Educação. 2.ed. Fortaleza: Gráfica Encaixe.

\section{REFERÊNCIAS DA INTERNET}

http://arlindocruz.com.br/2007-sambista-perfeito/. Acesso em 12.Nov.2016.

http://portal.mec.gov.br/component/tags/tag/34492. Acesso em 01.Nov.2016.

http://odia.ig.com.br/noticia/rio-de-janeiro/2015-10-14/o-meu-lugar-dearlindo-cruz-e-mauro-diniz-inspira-livro-de-cronicas-do-rio.html. Acesso em 12.Nov.2016.

http://www.planalto.gov.br/ccivil_03/Constituicao/hino.htm. Acesso em 01.Nov.2016.

Morgana Ribeiro dos Santos é Mestre em Língua Portuguesa pela UERJ. Doutoranda em Língua Portuguesa pela UERJ. Professora de Ensino Básico, Técnico e Tecnológico do Instituto Benjamin Constant, atuando no ensino de Língua Portuguesa a pessoas com deficiência visual. Participação do grupo de pesquisa Semiótica, Leitura e Produção de Texto - SELEPROT. E-mail:morgribeiro@gmail.com. 